This is the author's final, peer-reviewed manuscript as accepted for publication. The publisher-formatted version may be available through the publisher's web site or your institution's library.

\title{
Alan Seeger: medievalism as an alternative ideology
}

Tim Dayton

\section{How to cite this manuscript}

If you make reference to this version of the manuscript, use the following information:

Dayton, T. (2012). Alan Seeger: Medievalism as an alternative ideology. Retrieved from http://krex.ksu.edu

\section{Published Version Information}

Citation: Dayton, T. (2012). Alan Seeger: Medievalism as an alternative ideology. First World War Studies, 3(2), 125-144.

Copyright: ( 2012 Taylor \& Francis

Digital Object Identifier (DOI): doi:10.1080/19475020.2012.728698

Publisher's Link: http://www.tandfonline.com/doi/full/10.1080/19475020.2012.728698

This item was retrieved from the K-State Research Exchange (K-REx), the institutional repository of Kansas State University. K-REx is available at http://krex.ksu.edu 
Alan Seeger: Medievalism as an Altema tive Id eology

\author{
Tim Dayton* \\ Department of English \\ Kansas State University \\ Manhattan, KS USA 66502
}

*E-ma il: ta dayton@ksu.edu; Tel. 785-532-2155 
Alan Seeger: Medievalism as an Altemative Id eology

\begin{abstract}
The American poet Alan Seeger imagined the First World Waras an opportunity to rea lize medieval values, which were embodied for him in Sir Philip Sidney. Sidney epitomized Seeger's three ideals: "Love and Ams and Song," which contrasted with the materia lism and sophistic ation of modemity. His embrace of "Ams" and the desire for intense, authentic experience led Seeger, who was living in Pa ris in August 1914, to enlist in the French Foreign Legion, in which he served until his death in combat in J uly 1916. As an infantryman Seeger had extensive experience of the Westem front. This concrete experience of the war, of the indignities of life in the trenched and the dominance of technology, contrasted in significant ways with war asconstructed in Seeger's medieva list imagination.

Seeger, however, reconciled this contradiction by seeing the war as part of the elemental Strife of nature. By this means, Seeger avoided the potentially unsettling consequences of confronting the profoundly modem nature of the war. Interpreting the war as a form of "Strife" and as an assertion of medieval values allowed Seeger to imagine himself and his comrades to be living outside the world of industrial capita list modemity. Seeger shared with others involved in the warthis medievalism and the belief that the war offered relief from the values of modemity, even if Seeger's medievalism was more intense, more thoroughgoing, than was common. However, Seeger's death as a result of wounds received from machine gun fire vividly displays the contradic tion between his imagination and the rea lity of industria lized warfare.

The example of Seeger thus suggests that the American effort in the First World War was underwritten in part by an ideology through which a modem, industria lized war was embraced in terms derived from the imagined medieval past. Insofar as this is true medievalism functioned to provide an ideology that constructed, in the terminology of Raymond Williams, an altemative to the industrial capitalist modemity from which the waremerged, an altemative ideology that allowed the warto be imagined differently from what it was, but which posed no substantive challenge to the war's social and economic rea lities.
\end{abstract}

Keywords: war poetry; Alan Seeger; medievalism; ideology; modemity 
Alan Seeger: Medievalism as a n Altemative Id eology

Even prior to US entry into World War One, Alan Seeger was seen as the archetypal Americ an soldier-poet of the war. This status misleads slightly: Seeger was idiosyncratic in the intensity and consistency of his commitment to medieval and martial values. Yet, ultimately, those same medieval and martial values Seeger espoused consciously and delibera tely appear in a more diffuse form in the broader culture of the era. Thus Seeger and, the ava ilable cultural evidence suggests, the United Statesas a whole, engaged in the war on a paradoxical or perhapscontradic tory basis: the war was imagined as the opportunity to assert values eclipsed in, at the same time that the war itself took place at the cutting edge of, capita list modemity. Fought using the most recent developments of the second industrial revolution, propelled by the conflict between the "unlimited dynamism" imparted to Germany by "the imperative to expand of a massive capita list economy watching its statistic al curves so a ring up wa rd" and the United Kingdom, attempting to preserve its global economic and political domina nce, ${ }^{1}$ this striking ly modem war was imag ined in terms strikingly a na chronistic .

That Seeger wrote about the war in tems derived from an imagined premodem past is unsurprising: his background formed him in such a way that it would be astonishing had he not shared in the post-Romantic poetic culture analyzed by Paul Fussell, Ted Bogacz, Samuel Hynes, and others. Bom into an old 
New England family, Seeger attended the Hackley School in Tamytown, NY prior to entering Harvard as a member of the class of 1910. At Harvard, Seeger would eventually room with T.S. Eliot in his senior year, while Eliot was working on his Master's degree. ${ }^{2}$ After gra duating from Harvard, Seeger lived in Greenwich Village for a short time before moving to Paris, where he wasliving at the outbreak of the war. ${ }^{3}$ Shortly after the warbegan Seeger enlisted in the French Foreign Legion, motivated in part by his love for France but also by a deepseated desire to experience war: after Seeger died from wounds received in combat in J uly 1916, a friend wrote that Seeger fought on the side of the French because he had been living in France, as he would doubtless have fought on the side of the Germans had he been living in Gemany. ${ }^{4}$

The poetry Seeger produced out of the fulfillment of his desire for military experience contrasts sharply in form and content with the reaction aga inst the war in much of the canonic al Americ an litera ture, most prominently the work of E.E. Cummings, J ohn Dos Passos, and Emest Hemingway. Yet this desire for milita ry experience, which for Seeger was closely related to the desire to be a poet, was common in the late $19^{\text {th }}$ and early $20^{\text {th }}$ centuries in the U.S., partic ula rly a mong the middle and upperclasses; indeed, Cummings, Dos Passos, Hemingway, et al. had experiences to react aga inst because they shared, to a great extent, Seeger's cultural formation. But Cummings', Dos Passos', and Hemingway's writing about the war rejects signific a nt elements of that formation, and is thus less typic al of the Americ an culture that underpinned 
the war effort in 1917 and 1918 than is that of Seeger, whose

collected Poems were a non-fiction best seller in those years. ${ }^{5}$ Understanding Seeger helps one to understand more fully these canonic al writers by illuminating their cultural situation, while also revea ling the powerfully ana chronistic qua lity of the underlying culture mobilized in support of US intervention into the war.

\section{Seeger before the war}

In the spring of 1908 Seeger, then a sophomore at Harvard, wrote an essay, "Suggestions for a Dissertation on the Historic al Development of the Faustmotive." His professor for Compa rative Literature 7, M.A. Potter, responded favorably to Seeger's essay, part of which wasconcemed with the historical nature of the Renaissance, which Seeger presents as a play of new and old:

It is simple enough to see the new impulses, but what shall be said of the things that are no more, of the spinitual light that has vanished out of men's hearts? I suppose that it is only within recent years that the sophistic ation of three centuries has so farabated as to allow of a more correct and sympathetic estimate of the mediaeval world.

In this play of new and old, Seeger prefers the old: for him a baleful "sophistic ation" has overwhelmed the "spinitual light" of the medieval, a spintua lity that a ppeared to reassert itself before retrea ting once again: 
there was the sporadic impulse of the Romantic Revival, but not apparently based upon a mature enough selfconsciousness to atta in that perfection toward which it was progressing when blighted under the great retuming tide of materia lism that has afflicted the last half-century. ${ }^{6}$

Seeger wants to reverse this "tide of materialism" so that the "spinitual light" emanating from the medieval world might shine again.

Medieval settings or themes a re prominent in Seeger's prewar poetry: "Vivien," "Broceliande," and "Lyonesse," all work with tra ditional Arthurian material, while "Coucy" concems a castle in France that was home to several crusa ders. Less obviously med ieva list his poem "The Rendezvous" concems a lover awaiting his beloved in a Catholic church. He seeks out herface among the congregants:

But the long vespers close. The priest on high

Raises the thing that Christ's own flesh enforms;

And down the Gothic nave the crowd flows by

And through the portal's carven entry swarms.

Maddened he peers upon each passing face

Till the long drab procession teminates.

No princess passes out with proud majestic pace.

She has not come, the woman that he wa its. ${ }^{7}$ 
The setting in this poem derives its flavor in la rge part from the Catholic revival movement, a component of Victorian medievalism. The "Gothic nave" and the "portal's carven entry" provide a backdrop intended to make the lover's disappointment all the more poignant.

This penc hant for the medieval, for role-playing, and for a peculiar and crucial form of abstraction may be seen in a February 1916 letter that Seeger wrote while he recovered from a respiratory infection contracted in the trenches. He explains to his mother that in his first years at Harvard he was a devotee of Leaming for Leaming's sake.... The events of that life were positive adventures to me. Few, I am sure, have known more than I did then the employ of intellect as an instrument of plea sure. I shut myself off completely from the life of the University, so full, nevertheless, of pleasures. I sc offed at these pleasures that were no more to me than froth. I felt no need of comradeship. I led the life of an anchorite.

The choic e of tems is signific ant: while not an exc lusively medieval phenomenon, anchorites are strongly associated with the medieval. As a sort of anchorite, Seeger devoted himself to "Leaming for Lea ming's sake." The capitalization is typical of Seeger, who tended to abstract and to allegorize. This Leaming of his produced not, appa rently, knowledge or understanding, but plea sure; Seeger's sensibility was funda menta lly, a lthough complexly, 
hedonistic, as is seen further in his account in the same letter of his tuming away from Leaming. Comparing himself to characters in Balzac, Seeger says, "Obsessed by the buming vision of Happiness they left the quiet groves of the Aca demy and went down into the city in search of it." He continues: But my hedonism, if such it may be called, was not superficial like that of so many, to whom the emotional means only the sexual. I was sublimely consistent. For seeing, in the macrocosm, all Nature revolve about the twin poles of Love and Strife, of attraction and repulsion, so no less in the mic roc osm of my individual being I saw the emotional life equa lly divided between these two cardinal principles.... [M]y aspiration was to go all the gamut, to "drink life to the lees." My interest in life was passion, my object to experience it in all rare and refined, in all intense and violent forms. The war having broken out, then, it was natural that I should have staked my life on leaming what it alone could teach me. ${ }^{8}$

The capitalization continues in this passage, but now Seeger's abstraction and allegorization takes on a slightly different cast. First, the melodramatic qua lity of Seeger's imagination becomes even more prominent. But beyond this, his move into the abstract stands in curious relation to the desire for experience Seeger expresses in the letter. But then again, however concrete and particular any given experience may be, nothing is more abstract than Experience. 
This is not all. In his movement from whatever the partic ula rs of a given experience may be to the terms in which he understands it (Love, Nature, Strife) Seeger elides the rea Ims of the social and politic al: in his war poetry, the war will remain largely a matter, on the one hand, of sense experience and, on the other, of remote abstraction. Thus the war ra rely appears in his writing, either poetry or prose, as a politic a I conflict. While this elision typic a lly a llows Seeger to avoid types of ideology common in much of the American poetry of 1914-1918, it a Iso displacesideology to those levels that a re presented, most clearly but not exc lusively onto the abstractions, Love, Nature, Strife, Romance, etc., through which Seeger processes the partic ula rs of experience. Seeger thus a Iso displaces ideological conflict to the level of the imaginative, as when he makes an imagined medieval world or ima gined medieval figures repositories of a ntimodem values.

While Seeger attempts to expla in the varying pattems of his life in this letter to his mother, emp hasizing the break between his existence as an anchorite and as an active partic ipant in the world, a strong continuity underlies his concems: the medieval functions in the same manner in both the "Faustmotive" essay of 1908 and in his wartime writing. In the essay, Seeger imagines a break with "the sophistic ation of three centuries," with capita list modemity.

Clearly, such a change would be epochal, and Seeger becomes simultaneously apocalyptic and prophetic as he imagines the possibility: "Now we are dwelling in the uncerta in lull and sultriness that precedes a stom. Now we have reached 
the issue when materia lism has been weighted and found wanting." 9 Apocalypse and prophecy enter here in the figure of the waiting stom, a storm that would indeed break six years later with the advent of the war.

For Seeger, this sto m promises to end the era of materia lism that has so fardefeated the romantic retum to the spinitual.

What is to be the color of the dawning spinit? I fancy this: it is to be a new romanticism, a romantic ism based on a truer perfection of man's relation to Nature; it will be that renovation which shall be the death of all our shallow refinement that so unduly emphasizes the psychological in human interc ourse, which shaking off the tra mmels of a deadening sophistication shall retum to those purer ideals when mankind was only artistic a lly admissible in so far as entered into his proper relation to the universal and encompassing Beauty. ${ }^{10}$

Here, in this sophomore tem paper, much of the basis of Alan Seeger'scareer as a poet may be seen. Both Seeger's poetry and his embrace of the war emerge from his rejection of the materia lism and sophistic ation characteristic of life in the modem era. Seeger's program opposes what Fussell seesas characteristic of the response to the war. Fussell's "irony" is a sophistic ated response to the war. Seeger, even as an undergraduate, calls for a retum to a naïve sensibility. Seeger will advocate, and attempt to embody, a kind of new 
romantic ism that revives the values of the medieval world and aspires to the ideal. Seeger intends his medievalism, then, foremost as a rupture with modemity. ${ }^{11}$

\section{The Stom Breaks}

The deep-lying nature of Seeger's sensibility is glimpsed in the terminological consistency between the "Faust-motive" essay and his wa rime writing. In an essay published in the New York Sun in 1915 and later incorporated into his posthumously published Letters and Diary, Seeger refers to his unit's enc ampment as "romantic." 12 In a later artic le for the Sun, Seeger refers to going on a night reconnaissance patrol as "the one breath of true romance" to be found in "the monotonous routine of trench warfare" (Letters and Diary, 92). In one of his wartime sonnets, one in which he, atypic ally, imagines life after the war, he sees a future in which

... the great cities of the world shall yet

Be golden frames for me in which to set

New masterpieces of more rare romance. (Poems, 156)

Romance promises to restore to life the spinituality lost during three hundred years of "so phistic ation," three hundred years that correspond roughly to the era of capita list modemity.

Between 1914 and 1916, Seeger looked to the war to usher in the revived romantic ism he imagines in the "Faust-motive" essay, a romantic ism whose values opposed the "materialism" of capita list modemity. But as may be 
gleaned even in the brief quotation in which he refers to "the monotonous routine of trench warfare," the war does not offer the prospect of this romanticism in any unproblematic way. If patrols and raidsoffer the "one breath of true romance," then the nom of warfare experienced by Seeger and his comra des is that of "monotonous routine." Seeger desc ribed this routine at some length in an earlier article for the Sun. Trench warfare, dominated by a rtillery, "is extremely modem, and for the artilleryman is doubtless very interesting, but for the common soldier, is a nything but romantic" (Letters and Diary, 29). The warthreatens to be a nother version of the very modemity that Seeger hopes to see ended by the stom that is the war. Indeed, trench warfare tra nsfo ms soldiers into the very embodiments of monoto nous routine: ind ustria I workers.

Seeger writes that as aftemoon shades into evening, and the artillery fire ends, "Everybody tums out like factory workmen at 5 o'clock" (Letters and Diary, 37). This most unspintual experience of war emphasizes the basic material aspects of existence, and threatens to provide the basis not of a new romantic ism, but of a kind of ultra-ma teria lism. Seeger allows this critic ism of modem warfare to be voiced most powerfully by a Serbian comrade: It is ignoble, this style of warfare, he exclaims. Instead of bringing out all that is noble in a man, it brings out only his worse self-meanness and greed and ill temper. We are not, in fact, leading the lives of men at all, but that of a nimals, 
living in holes in the ground and only showing our heads

outside to fight and to feed. (Letters and Diary, 31)

So reduced is the existence of the soldier in trench warfare that "the matter of eating assumes an importance altogether a musing to one who gives it only very sec ondary consideration in times of peace" (32). War, rather than resc uing life from the materialism of modemity, threatens to intensify modemity, lowering one even further from the spinitual.

At this point Seeger withdraws from the nega tivity of his portra it of trench warfare and presents a more pleasing vision. Describing sentry duty, Seeger notes that "the sentinel has ample time for reflection. Alone under the stars, war in its cosmic rather than its moral a spect revea ls itself to him" (Letters and Diary, 38). Seeing the remote stars transports him to the cosmic plane, a way from the sord id materia lity that surround shim, and puts him in mind of the spinitual meaning of the war, which for Seeger lies in participation in the elemental "Strife" of nature. Spintual mea ning overcomes material being, and war's romance retums; rejoined to the timeless demands of nature, warleads away from, rather than further into, modemity. ${ }^{13}$

Here Seeger shifts from the immediate conditions in which he experiences warfa re-conditions that render it disturbingly modem-and places it within what he understands to be a larger signific ance. By doing so he shifts from the human world to the realm of nature and elemental forces, skipping altogether the dimensions of the social and the political, through which human experience 
of nature is mediated. Seeger thus reifies — out of a subjective necessity-the very realm of experience to which he resorts as an escape from the modem, material rea lity of the $20^{\text {th }}$ century. Having initially acknowledged the modem, unromantic nature of his war experience, he then places it within the context of an all-embracing and unmediated Nature. This recontextua lization makes possible the project imagined in the "Faust-motive" essay, that of a new romanticism that would revive the spintual values of the medieval world.

\section{Love and Ams and Song}

The nature and function of the medieval in Seeger's poetry is most visible in the first sonnet from the "Last Poems" section of his Poems: Seeger wrote the entire section after the warbegan, and the warprovides the topic of or a signific ant backdrop to all the poems in it. In the first of a series of sonnets, Seeger a postrophizes Sir Philip Sidney:

Sidney, in whom the heyday of romance

Came to its precious and most perfect flower, Whether you toumeyed with vic torious lance

Or brought sweet roundelays to Stella 's bower, I give myself some credit for the way I have kept clean of what enslaves and lowers, Shunned the ideals of our present day And studied those that were esteemed in yours; For, tuming from the mob that buys Success 
By sacrific ing all Life's better part,

Down the free roads of human happiness

I frolicked, poor of purse but light of heart,

And lived in strict devotion all a long

To my three idols -- Love and Armsand Song. (Poems 145)

The object of this address, Sidney, functions as the ideal of ma nhood, the "perfect flower" of the "heyday of romance." Sidney, of course, was not really a man of the medieval era, but Seeger betrays a simila rity with his old college roommate, Eliot. Writing a bout Eliot, Mic ha el Alexander comments that his "English history is not medieval, but is taken from the period between the executions of Mary Queen of Scots and those of Laud and CharlesI. The Ca roline spintua lity ended by the Cromwellian reformation figures as a little Middle Age of Anglic a nism."14 But Mark Girouard notes that, "In England, media eval chivalry had an Indian summer during the reign of Eliza beth-a summer which lasted on into the early seventeenth century." 15 When Eliot and Seeger use this "little Middle Age" as a repository of anti-modem values, they draw upon elements actually present in Eliza bethan culture although seemingly at variance with important developments in Tudor society.

Seeger, as did Eliot, would have seen Sidney's likeness regula rly as an undergraduate, pictured in stained glass wind ows in Harvard's Memorial Hall. Sidney is portrayed three times in these windows. The upperportion of window number five in what is now Annenberg Hall (fig. 1) shows Sidney holding in his left 
hand a piece of papercontaining lines from the Old Arcadia, with a sword at his hip: poet and warior. The lower portion represents the scene related by Sidney's friend and first biographer, Fulke Greville, in which Sidney, woundedsomewhat ironic ally given his function for Seeger-by a bullet at the Battle of Zutphen, gives his water bottle to a fellow casualty with the words, "Thy necessity is yet grea ter than mine." 16 The wind ow displays Sidney as a poet and a wamior, selfless and valiant. Sidney appears aga in in the south transept window in another representation of the same scene. Here the scene functions somewhat differently than does the one in Annenberg Hall; in the south transept, "general and ideal" figures of "the Soldier (or Knight) and Scholar" flank "concrete examples of virtues which should characterize these ideals."17 In the first case, the wounded Sidney plays out a characteristic scene from his life. In the second, he providesa concrete illustration of right behavior on the part of the abstract Soldier.

In this Shakespea rean sonnet, Seeger asserts that Sidney embodies values alien to capitalist modemity. The first stanza celebrates Sidney, noting in partic ular his ma rtial prowess, his ostensible devotion to Penelope Devereux, and his poetic skill, while the second stanza presents the speaker as a student of Sidney. Stanzas three and four become slightly more concrete, and we see what it means to pattem oneself on Sidney, or on the ideals esteemed in his day, which entails rejecting material success and wealth in favor of devotion to "Love and Ams and Song." By patteming himself along the same lines as those 
he imagines to have defined Sidney, shunning "the ideals of our present day," the speaker positions himself as non-contempora neous with the commercial soc iety of capita list modemity.

Seeger, then, based his life and his poetry on a medievalism that led him to idealize the past, yet also, in an irony of which he seems una ware, led him to idea lize the present in the form of the First World War, a war he saw as the proper site for the practice of his devotion to "Arms and Song," and which lent special poignancy to "Love." Seeger sought in the imagined past, of which Sidney is the "most perfect flower," an a ltemative to the world of ind ustrial capita list modemity. In this, Seeger follows in the footsteps of the late19th century a ntimo dem milita rism. This a ntimo dem milita rism typic a lly favored medievalist forms of expression, with the medieval knight being the preferred means for expressing the ideal of martia I virtue. According to T. J J ackson Lears, two versions of the knight were dominant in late-Victorian America: the Galahad figure and the Saxon. ${ }^{18}$ The Galahad figure emphasizes purity and the Saxon a kind of ferocious vita lity, but Seeger's Sidney provides a n attractive a ltemative because his status as a poet a llowed Seeger to synthesize the martia I ideal with the religion of beauty, a variant of $19^{\text {th }}$ century medievalism. Unlike Galahad or the Saxon, Sidney was a lover, a fighter, and a singer: the quintessence of Romance.

The list with which Seeger concludes this sonnet, "Love and Ams and Song," provides the topics of the sonnet sequence which the apostrophe to 
Sidney initia tes. Eight of the sonnets concem Love, a topic Seeger tums in various ways. For example, the fourth sonnet approacheslove in the manner familiar from the religion of beauty. In what might also serve as a reasonably accurate summary of Seeger's work, the religion of beauty is described as "a protest aga inst the religion of Self, of Materialism, and of Worldly Advancement."19 This religion of beauty a ppears throughout Seeger's poetry and, like the earlier form of medievalism from which it descends, Seeger's version of the religion of beauty presents the singleness of its obsession as an altemative to the practical da ily-mindedness of commercial society. Compared to the religion of beauty, religion as such pales, becoming part of the routinized world, like that of world of the office and shop, aga inst which the speaker rebels. The sonnet ends:

Enchanting girl, my faith is not a thing By futile prayers and vapid psa Im-singing

To vent in crowded nave and public pew. My creed is simple: that the world is fair, And beauty the best thing to worship there, And I confess it by adoring you. (Poems 148) Love and song meet at this point: the object of love is the "enchanting ginl," who provides the subject of the poem, which as art is also a form of the bea utiful. Seeger's immersion in beauty sets up a model of human subjec tivity 
and a set of values that seem to provide an altemative to those dominant in ind ustrial c a pita list soc iety.

\section{The Warior Elite}

After a series of poems dedicated to love, Seeger concludes the sequence with two poems, one contrasting the men at the front and those who are not, and the other an anticipation of life after the war. Sonnet XI, "On Retuming to the Front after Leave," retums to Seeger's conception of war in its social aspect: soldiers a re the elite, forming a community whose willingness to sacrifice themselves and whose commitment to one a nother contrast with the ruling individua lism of peacetime existence.

Apart sweet women (for whom Heaven be blessed), Comrades, you cannot think how thin and blue Look the leftovers of mankind that rest, Now that the cream has been skimmed off in you. War has its horrors, but has this of good --

That its sure processes sort out and bind Brave hearts in one intrepid brotherhood And leave the shams and imbeciles behind. Now tum we joyful to the great attacks, Not only that we face in a fair field Ourvaliant foe and all his deadly tools, But a lso that we tum disda inful backs 
On that poor world we scom yet die to shield --

That world of cowards, hypocrites, and fools. (Poems 155)

A variant form, Sonnet XI combines the relaxed myming demands of the Shakespearean sonnet with the strong division between octave and sestet of the Petrarchan sonnet. After women are exempted from critic ism in the first line, the remainder of the poem contrasts two orders of men: the "leftovers" who do not fight, and the "cream" who do, and to whom the sestet is dedic ated.

Praising warfor separating these two orders of men occupies the second half of the octave. The characterization of the impact of war on those who fight, to "bind/Brave hearts in one intrepid brotherhood" is consistent with Seeger's contrast elsewhere between the possessive individualism of ordinary existence and the higher community to which warcalls one. Seeger celebrates a version of a "socialism of war," "the ideal of a more intimately and orga nically united community, forged upon the shared experience of danger and war,"20 widespread in the early days of World War One.

The sestet of "On Retuming to the Front after Leave" combines an arc ha ic conception of war with an ironic conception of its function: a split more dramatic than it may initially a ppear. Seeger and his comrades "tum... joyful to the great attacks," an attitude diffic ult to comprehend, and perhaps believe, especially given that the great mutinies in the French a my were only about a year off. The "valiant foe" is met in a "fair field," a conception of the war unusual in American poetry since the need to mobilize the Americ an population 
to support a waragainst an enemy incapable of directly threa tening the security of the Americ an mainland led to characterizations of the enemy tending toward the demonic, negating the generosity to one'sopponent prescribed by the chivalic code. ${ }^{21}$ And the landscape produced by the war can hardly be described as a "fair field." In this field the foe wields "deadly tools," a surreptitious a cknowledgement of the mechanized nature of modem warfare, perhaps, but in language that actually evades the real nature of these "tools," whether machines or chemic al compounds, as products of the second ind ustrial revolution. Such language is a n example of the high diction analyzed by Paul Fussell and by Ted Bogacz, who describes it as "an abstract euphemistic language.... This elevated language is not rooted in observed reality; rather, it could all too easily be used by a writer to ignore or obfusc a te his and others' experiences."22 While Seeger's language certa inly does this, it also must be seen to emerge from Seeger's program to realize a new, medievalist, romance.

Still, a potentially discordant note enters: that the soldiers in facing their foes tum their backs on those at home uses a schematized vision of the confrontation to pass judgment on those who rema in behind, thus setting up an irony, the ramific ations of which Seeger does little to explore. The soldiers' "disda inful backs" are tumed "On that poor world we scom yet die to shield." This contempt for those not at the front is the negative obverse of the "intrepid brotherhood" of those who fight, but was a feeling pervasive not only in Seeger, but in the writing of veterans of the various countries involved in the war. The war 
inspired a widespread sense that it called people to a higher form of community and that in enabling community to trump the marketplace, the war transcended ordinary pre-war existence. While this sense of solidarity was-at least at the start of hostilities-experienced throughout the societies engaged in the war, Seeger limits the experience to the soldiers who serve at the front, anticipating the ideology of the frontsoldat that emerged most fa mously-and disastrously--in Gemany during the postwar period, but the basic elements of which were common to many of the ammies. ${ }^{23}$ Yet Seeger himself does not develop or explore this irony, as indeed he cannot without abandoning his attempt to resurrect the naïve and wholehearted embrace of the ideal.

For Seeger fighting in the warand writing poems about it contrasted with modem existence, dominated by commercial values, distracted by the pursuit of the false and the trivial. For Seeger, fighting, preferably for France, perhaps, but often in his writing, simply fighting, offered an opportunity to be part of a fundamental a nimating principle of existence: "Strife." As a n elemental part of rea lity, war provides a means of access to experience that lies beyond the "Getting and spending" with which, Word sworth famously tells us, "we lay waste our powers." 24 In "The Hosts," the combatants are:

Purged, with the life they left, of all

That makes life paltry and mean and small, In their new dedication charged With something heightened, enriched, enlarged, 
That lends a light to their lusty brows

And a song to the mythm of their trampling feet. (138)

As is typical in Seeger, and there will be more of this in "The Hosts," the war revivifies those who fight, those who have broken with the routines of domestic life.

Certa inly, the belief that exposure to warbenefited men wascommon among the educated elites of this period. At the most general level, martial virtue and the rigors of sold ienly life were contrasted with the sloth and ea se into which developed industrial societies had fallen. Such fears and contrasts were fueled in part by the inherited anxieties of the republic an political tradition, with its view of the inevitable degeneration of societies once succ essful republic an polities provided a standard of material comfort that threatened to lapse into the dreaded contagion of luxury. While the republican tradition predates ind ustrial capitalism, the course of the Americ an 19th century ensured that its anxieties would be well aroused at the opening of the 20th, with the emergence of a reasonably large, prosperous, and educated social elite..$^{25}$

\section{VI. "All are made one"}

The martial ideal is clearly artic ulated in three essays written by people affilia ted with Harvard University during Seeger's time there. The Harvard Monthly, where Seeger went on to serve as an editor and to publish a number of poems, ${ }^{26}$ published two essa ys a bout military training, Louis Grandgent's “Camp Sketches" in1908 and Richard Douglas' “A Rookie in the War Game” in 1909. 
Like Seeger, Grandgent presents military experience as a dramatic break from the civilian nom, “... in lively, roma ntic, strenuous qualities no ga me sumasses the game of war.... the isolated nature of military training binds the participants together and lends to their life a peculiar charm."27 Grandgent's list of the qua lities that distinguish "the ga me of war" is signific a nt: "lively," not dull; "romantic," not humdrum; "strenuous," not lethargic, a list to which Seeger would no doubt assent. Beyond this, Grandgent and Seeger share the conception of "the game of war," although Grandgent's experience was litera lly of war as a game, while the game-like quality of war in Seeger emerges from his sensibility, not from his experience of war, since this was of a deadly serious cha racter.

As will Douglas and Pemy, Grandgent emphasizes the democratic nature of military experience: it brings together a cross-section of Americ an soc iety: They are of all kinds,--white and black, regulars and militia, infa ntry and cavalry, artillery and engineers; and whether they hail from Virginia or northem New York, these are all in the same service as yourself. Some come from the mass of factory hands, some from farms, some are doctors and lawyers in fashionable organizations, some have been tramps; but all are made one by the uniform of the American sold ier. ${ }^{28}$ 
Military service becomes a way of reestablishing the organic community that has disintegrated under the pressures of modemity. Striking a note that will be repeated in countless poems written during the war, Grandgent presents regional and class differences as dissolved by the unifying force of "the uniform of the Americ an soldier." In Douglas, a Iso, military experience levels in a way that does not challenge social hierarchy, even as it tempora rily erases it. A corporal "bosses a gang of former lawyers, doctors, and professional men, now doing dago-work for the good of the service."29 The community of the battalion makes these men willing to do "dago-work" and thus levels; yet the work rema ins "dago-work."

Also emphasizing the commonality of military experience is Harvard philosophy professor Ra Iph Barton Perry, who published “Impressions of a Plattsburg Recruit" in The New Republic. The Plattsburg camp that Pemy attended resulted from a movement to provide military training to American men in a format similar to that of a summer camp. Like his fellow Plattsburg rec ruits, then, Perry was a civilian. Yet Pemy, and apparently his fellow "recruits," felt the same sense of unity as that to which Douglas and Grandgent, who tra ined with the National Guard, attest:

Soldienly experiences are common experiences, and a re hallowed by that fact.... To walk is one thing, to march, albeit with sore feet and aching back, is a nother and more triumphant. It is “Hail! Hail! The gang's all here," or “Glorious! 
Glorious! one keg of beerfor the four of us"-it matters not what the words signify, provided they have a rhythmic swing and impart a choral sense of collective unity. Special privilege and personal fastidiousness, all that marks one individual off from the rest in taste orgood fortune, seeks to hide itself. Instead there is the common uniform . . . 30

Appa rently, the "so cia lism of war" does not a bsolutely require war, or even membership in an organized military unit. Tra ining for wa r suffic es to eliminate those marks of distinction that in other contexts a re not hidden, but rather displayed. Again, community and commonality are achieved through the mechanism of military tra ining and experienced within a hiera rchic al community imagined as organic. Military experience generally, and not just war, appeared to provide what Eric J. Leed calls "a means of transcending social and economic contradictions." 31

But this supposed transc endence was based fimly on those selfsame contradictions. Lears describes the appeal of militarism to the Americ an upper class because of its utility in ra llying the restive lower orders a round the American flag. In a ddition to remaking society without class a nta gonism, war seemed a good way to reinvigorate upperclass manhood, and thus also to reassert the leading role of the elites:

"Idleness and luxury have made men flabby," a North Americ an Review contributor observed in 1894, wondering "if 
a great war might not help them to pull themselves together." Imperialist adventures offered a chance for enervated young men to follow Franc is Parkman's presc niption: "to realize a certa in ideal of manhood-a little medieval." As the Century wrote in 1898 , the contemporary passion for war signa led a yeaming for purific ation: "we think of war nowadays, not so much as being a means of making others suffer a san occasion for giving ourselves up to suffering." 32

By embracing suffering, the martial ideal contrasted itself with the unheroic nature of bourgeois existence; at the same time, shunning the life of ease opened the way to a type of ascetic ism, one that complements rather than contrad ic ts Seeger's hed onism: both a sc etic ism and hedonism offer intense experience. Gemeinshaft and powerful experience, a heady combination for Seeger and, apparently, for many others.

\section{The Wamior Eite, Soc iety, and Strife}

In his desire to experience war, Seeger exemplified "the milita rist search for a uthentic ity." But embracing the martial ideal not only sa tisfied a subjective need for authenticity, it a lso provided a reassuning sense of girding oneself against the threat posed by the lower orders: the militant tra de unionists, soc ia lists, a na rc hists, and immigrants that, however unfa shiona ble they may have been, appeared to posses in abundance the vita lity that the upperclass 
feared it waslosing, indeed, was fated to lose according to the republican vision of history. In his writing Seeger emphasizes the personal, not the social, value of martial idea ls and experience. However, Alan's older brother Cha rles believed that the Seeger children were ra ised within a clear set of social values. He considered his father the "snobbest of the snobs," and summarized his soc io politic al outlook:

Seventy percent of the human race was fit only to be govemed; a nother twenty percent was intelligent enough to act under direction; the remaining ten percent was constituted by the competent who had the discipline, the sense of moral duty and physic al ability to give that direction for keeping the remaining seventy from mere savagery and anarchy. It was taken for granted that we children inherited the qualific ations and duties of membership in this ten percent.

Charles felt that it took enomous effort to overcome "the 'anti-lower class' attitude that he had imbibed from his father and the rest of the Seeger clan."33 Raised in the same environment as his brother, Alan was exposed to the same attitude. While Charles struggled aga inst it, the role of "the elite" in his poetry suggests that Alan did not, or rather that he transformed the social elite of his father into a wa mior elite. ${ }^{34}$ The attributes required of the "ten percent," 
"discipline, the sense of moral duty, a nd physical ability," demonstrate how easily Seeger would have associated the martial, asc etic ism, and elitism.

For Seeger, military service calls to and creates a class of supermen, a term he uses in the letter in which he recalls his former dedication to Lea ming. In “The Hosts," Seeger celebrates these supemen:

These are the men that have taken vows, These are the hardy, the flower, the élite,-These are the men that are moved no more By the will to traffic and grasp and store And ring with pleasure and wealth and love The circles that self is the centre of; But they are moved by the powers that force The sea for everto ebb and rise, That hold Arcturus in his course, And marshal at noon in tropic skies The clouds that tower on some snow-capped chain And drift out over the peopled plain.

They are big with the beauty of cosmic things. (Poems 138) War destroys the economic rationa lity and egoistic calculation that the ideologues of capita lism eleva te as the grea test of all virtues. In so doing, war retums men to the world from which they have been sundered. War allows the combatants to reorient themselves in line with the elemental forces of nature. By 
doing so, they become ironic ally fertile, pregnant in fact, "big with the beauty of cosmic things," ministers not of death and destruction, but of life and beauty because war provides relief from the values and habits of life in market soc iety. In "The Aisne (1914-15)" he writes,

For that high fellowship was ours then

With those who, championing a nother's good,

More than dull Peace or its poor votaries could,

Taught us the dignity of being men. (Poems 132)

"High fellowship" and "championing another'sgood" are not values of the competitive marketplace. As with Seeger's attitude towa rd wa rfa re generally, his transcendence of self, accomplished through warfare, is mediated by the transformative power of a medievalist imagination.

\section{VIII. "There was only an industrial world"}

Seeger imagines military experience to provide an escape from and an altemative to the a lienating individua lism of modemity; in doing so it provides a means by which to retum to the idea Is of Sir Philip Sidney and "the heyday of romance." Yet the kind of military experience Seeger und erwent was decidedly modem. Leed argues that the First World War destroyed the illusion that military experience lies apart from ordinary modem experience: "In warcombatants lea med there was only an ind ustrial world, the rea lity of which defined them much more in warthan it had in peace. In the trenches men leamed that mechanized destruction and industrial production were mirror images of each 
other."35 Some combatants leamed this. Not Alan Seeger. Indeed, the lesson that Leed asserts was taught to men in the trenchesappears to have been leamed less frequently than Leed suggests, at least by Americ an soldiers. J ona than Ebel argues that the ind ustria lized violence of the Westem front prompted many Americ an soldiers and war workers to make sense of their experience in religious, predominantly Christian, tems. ${ }^{36}$

This Christian theo logizing of the war finds a signific a nt point of contact with Seeger's poetic imagination in the figure of the Crusader, which combines Christia nity with military violence. Part of the larger pattem of medievalism, the Crusa der appears throughout Americ an literature and culture during 1917 and 1918. ${ }^{37}$ The poster for the movie Pershing's Crusaders (Fig. 2) provides a sense both of this pervasiveness and of the function served by medieva list disc ourse and iconography. The visual logic of the poster is obvious enough: the American Expeditionary Force led by General Pershing represents a modem version of the Crusaders of the middle ages. The Crusaders a re understo od, as they must be for the logic to be effective, as unproblematic moral agents: the Crusa des are not political, are unta inted by involvement with the economic, and so too by extension is its modem counterpart. The whiteness of the Crusaders' robes and horses express visually this purity.

Seeger's medievalism did not typic ally ma nifest itself in tems of the Crusades. Yet he would have been exposed to their ic onography as an undergraduate at Harvard. As was Sidney, both abstract and concrete 
Crusa ders were represented in the stained glass of Memorial Hall. The upper portion of wind ow number thirteen depic ts an abstract Soldier, a rrayed as a Crusa der. The lower portion depicts the crusa der charging on his steed. Window number twelve depicts a specific Crusader, Godfrey of Bouillon. Seeger's medievalism was thus nurtured and reinforced by the culture a round him, even as medievalism seemed to provide an a ltemative to the values dominant in the society. Alisa Miller has argued that Seeger's life and writing "supplemented the metoric established by the propaganda, official and unofficial, being produced by the Entente nations as well as by interested individuals and groups in the United States." 38 The full truth of this emerges when one examines the imag inative framework of Seeger's writing, especially medievalism a nd values associated with it.

Given that Seeger reacted against the cultural effects of industrial capitalism by embracing medieva lism and the martial ideal, his death from wound seceived in combat becomes deeply ironic. Seeger died in a minor operation aspart of French support for the British in the Battle of the Somme. Thus Seeger was one of a round 200,000 French casualties killed or wounded, or one of over 600,000 Allied ca sualties, or a round 1.2 million tota I c a sua Ities killed or wounded in the battle between 1J uly and 18 November $1916 .{ }^{39}$ Seeger died as a result of machine gun fire, not only a common cause of death in the war, but one that reveals the strikingly modem and industrial character of the 
wa rfa re experienced by soldiers like Seeger. In The Face of Battle, J ohn Keegan characterizes the machine gun:

a machine, and one of a quite advanced type, similar in some respects to a high-precision lathe, in others to an automatic press. Like a lathe, it requires to be set up, so that it will operate within desired and predetermined limits; this was done on the Maxim gun, common to all a mies of 1914-1918, by adjusting the angle of the barrel relative to its fixed fining platform, and tightening or loosening its traversing screw. Then, like a n automatic press, it would, when actuated by a simple trigger, begin and continue to perform its functions with the minimum of human attention, supplying its own power and only requining a steady supply of raw material and a little routine ma intenance to opera te throughout a working shift. The machine gunner is best thought of, in short, as a sort of machine-minder....40

Seeger, as did many others, died as the result of someone's routinized la bor, in which the machine technology characteristic of the second industrial revolution was applied to the business of killing people.

Obviously, Seeger's perception of himself and what he was engaged in on that day in 1916 are remote from war as Keegan, Leed, and others describe it. In this, Seeger is simulta neously id iosyncratic and typical. He is idiosyncratic 
precisely in the way indicated by the comment of an acqua intance: "Alan was consistently medieval." 41 Seeger's medieva lism, his construction of himself as non-contemporaneous, wasmore thoroughgoing than wascommon, and to this extent idiosyncratic. Seeger did not merely tra nsmit a received ana chronistic culture. He developed his a nachronism precisely a s a counter to capitalist modemity and its attendant values and culture. Paul Fussell emphasizes the persistence of "the old metoric" and Ted Bogaczargues that this persistence was not a matter of simple inertia but rather "a defense and ba mier against a threatening modem world." 42 Seeger's medieva lism, part of a more general a nachronism of which "the old rhetoric" and high diction are a part, provided an ideologic al a ltema tive to modemity, an a Itema tive Seeger consciously and actively cultivated. While Seeger's is an extreme case of the anachronistic imagination, it providesa sense of the imaginary a ltemative supplied by anachronism in less extreme cases.

This altemative should not be seen as altogether false. As Lears points out, the martial ideal "contains an ad mirable streak of honest sto ic ism" necessa ry to confront the element of pain that life entails, but that the culture of consumption evades. In this way Seeger's contrast between the elemental reality of his milita ry experience and the distracting superfic iality of "getting and spending" conta ins a critical component. Yet medievalism ultimately fa iled to pose any signific ant challenge to the culture of consumption, the second ind ustrial revolution, or ca pita list modemity more generally. In Seeger a nd in the 
broader war culture, medievalism functioned as an a ltemative ideology in the sense developed by Raymond Williams, a set of meanings and values that differed from that of an enveloping ind ustrial ca pita list modemity. ${ }^{43}$ But even Seeger' s a c tively and consciously constructed medieva lism remains only altemative and not, in Williams' terminology, oppositional. Indeed, insofar as the First World Wa roccurred within, not aga inst, capita list modemity and is a part of its unfold ing dyna mic, medievalism was largely incorporated by the capitalist modemity it scomed, providing Seeger and others with vital self-deceptions that helped enable one of modemity's greatest atrocities.

\section{Ac knowledgement}

I would like to thank Angela Hubler, who patiently read several drafts of this essay and made many useful suggestions and Rebecca Margolies, who provided key research assistance.

\section{Notes}

1Hobsbawm, Age of Empire, 318-319.

2 Miller, T.S. Eliot, 58.

3 Hart. "Alan Seeger," 372. This period is the least well-documented of Seeger's life. The nature of his time in Paris, in particular, has largely to be construed from his poetry or inferred from later personal writing.

4 Reeves, "Tragedy of Alan Seeger," 160.

${ }^{5}$ Bowker's Annual/Pub lisher's Weekly. «http:// www3.isrl.illino is.edu/ unsworth/ courses/bestsellers/best10.c gi> (ac cessed 24 September 2009). According to Van Wienen (Partisa ns and Poets, 6), Seeger's Poems saw eight printings and sold 28, 375 copies by the end of the war.

6 This and the preceding quotation are from Seeger, "Suggestions," 1.

7 Seeger, Poems, 99. Further c itations to this work a re given in the text.

8 This and the preceding quotation are from Seeger, Letters and Diary, 184-85. Further c itations to this work a re given in the text.

9 Seeger, "Suggestions," 1.

$10 \mathrm{lbid}$. 
11 Seeger's medieva lism thus differs from British and German medieva lism as a na lyzed by Stefan Goebel. Goebel empha sizes the "assertions of continuity" with "a remote yet meaningful past" (Great War and Medieval Memory, 287, 286)) in war memoria Is. While he acknowledges the attempt to ma inta in a sense of continuity in war memoria ls, Sa muel Hynes (War Ima gined) emphasizes a more widespread sense of disc ontinuity in his survey of English culture and the war from 1914 to 1933. This disc ontinuity was occasioned by the war. But unlike Seeger's, the disc ontinuity Hynes perceives was more comprehensive: the warput the lie to much of the past, including Seeger's beloved romance.

12 Seeger, Letters and Diary, 56, 60.

13 Seeger thus joins the tra in of writers a nalyzed by Paul Fussell for whom the sight of the sky was freighted with meaning (Great War, 51-63).

${ }_{14}$ Alexander, Medievalism, 231. Mary was executed 8 February 1587, while Sidney, who died 17 October 1586, was interred in the old St. Paul's 16 February 1587. Laud was behea ded 10 J anuary 1645, and Charles I followed him $30 \mathrm{~J}$ a nuary 1649.

15 Girouard, Retum to Camelot, 17.

16 Greville, Life of Sir Phillip Sidney, 130.

17 Hammond, Sta ined Glass Wind ows, 291.

18 Lears, No Place of Grace, 100.

19 Galloway, "Translator's Preface," vii.

20 Losurdo, Heideger, 13, 15.

${ }^{21}$ David Kennedy argues that the manner in which the U.S. war effort was financed also contributed to this demonization of the enemy, since the Liberty bond campaigns relied upon stiming the emotions of the public to be suc cessful (Kennedy, Over Here, 104-5). He also points out that the Food Administration's reliance upon voluntary efforts led to similar techniques (11819). See also Nicoletta Gulace, "Barbaric Anti-Modemism," 72-3.

22 Fussell, G reat War, 21-3 and Bogacz, 649.

23 Leed, No Man's Land, 39-72, 193-213; Losurdo, Heideger.

24 Wordsworth, William Word sworth: The Poems, 568.

25 Lears, No Place of Grace, 97-139.

26 "Editors of The Harvard Monthly," 4.

27 Grandgent, "Camp Sketches," 173.

28 Ibid., 174.

29 Douglas, "Rookie," 71. David Kennedy comments that advoca tes of universal milita ry training "seemed... to offer military service not as a means to achieve equality, but as a substitute for it" (146).

30 Perry, “Impressions," 231.

31 Leed, No Man's Land, 193.

32 Lears, No Place of Grace, 112.

33 This and the preceding two quotations are from Pescatello, Charles Seeger, 33, 24, 62.

34 Heinz Eulau mentions Seeger as a member of the Harvard Socia list Club ("Mover and Shaker," 293). Otherwise, nothing suggests that Seeger had a ny interest in socialism.

35 Leed, No Man's Land, 194.

36 Faith in the Fight, 54-75,

37 On the pervasiveness of the Crusades and crusa ding in American World War One disc ourse, see Ebel, Faith in the Fight, 34-38. See also a poem such asEdward S. van Zle's “Rise Up! Rise Up, Crusaders!" Goebel disc uses crusa ding in British culture, esp. pp. 86-91 and 115-19, as does Elizabeth Sibemy, New C rusa ders, 87-103.

38 Miller, "Alan Seeger," 18.

$39 \mathrm{~J} \mathrm{ohn} \mathrm{Keegan,} \mathrm{First} \mathrm{World} \mathrm{War,} \mathrm{298-99.}$

$40 \mathrm{~J} \mathrm{ohn} \mathrm{Keegan,} \mathrm{Face} \mathrm{of} \mathrm{Battle,} 230$.

${ }^{41}$ Quoted in Howe, Memoirs of the Harvard Dead, 116. 
42 Fussell, Great War, 23; Bogacz, “A Tyranny of Words," 664.

42 Williams, "Ba se and Superstructure," 39.

\section{References}

Alexander, Michael. Medievalism: The Middle Ages in Modem England. New Haven, CT: Ya le University Press, 2007.

Bogacz, Ted. "'A Tyranny of Words': Language, Poetry, and Antimodemism in England in the First World War." The J oumal of Modem History 58.3 (1986): 643-668.

Bowker's Annual/ Publisher's Weekly.http://www3.istl.illinois.edu/ unsworth/ courses/bestsellers/best10.c gi (accessed 24 September 2009).

Cottier, Daniel. Sidney and Epaminondas. 1879. Memorial Hall, Harvard University. http://www.fas.ha va rd .edu/ -memhall/art/ wind ow05.jpg Douglas, Richard. "A Rookie in the War Game." The Harvard Monthly 48 (1909): $68-76$.

Ebel, J onathan H. Faith in the Fight: Religion and the American Soldier in the Great War. Princ eton, NJ : Princ eton University Press, 2010.

“Editors of The Harvard Monthly." The Harvard Monthly 50 (1910): 1-4.

Eulau, Heinz. “Mover and Shaker. Wa Iter Lppmann as a Young Man,” Antioch

Review 11 (1951): 291-312.

Fussell, Paul. The Great War and Modem Memory. New York: Oxford University Press, 1975.

Galloway, M.A.A. "Translator's Preface." Robert de La Sizeranne, Ruskin and the 
Religion of Beauty. London: George Allen, 1899.

Girouard, Mark. The Retum to Camelot: Chivalry and the English Gentleman.

New Haven: Yale University Press, 1981.

Goebel, Stefan. War Remembrance and Medievalism in Brita in and Germany, 1914-1940.Ca mbridge, UK: Cambridge University Press, 2007.

Grandgent, Louis. “Camp Sketches." The Harvard Monthly 47 (1908): 173-81.

Greville, Fulke. Life of the Renowned Sir Philip Sidney. London, 1651.

Gulace, Nic oletta. "Barbaric Anti-Modemism: Representations of the 'Hun' in Brita in, North America, Australia, and Beyond." Pic ture This: World War 1 Posters and Visual Culture. Ed. Pearl J a mes. Linc oln: University of Nebra ska Press, 2009. 61-78.

Hammond, Mason. The Stained Glass Windows in Memorial Hall, Harvard University. ts. Copy corrected through 1983. Harvard University Fine Arts Library, Cambridge, MA.

Hart, J ames A. "Alan Seeger." American Poets, 1880-1945: First Series. Ed. Peter Quartemain. Dictionary of Literary Biography. Vol. 45. Detroit: Gale, 1986. $371-75$.

Hobsbawm, Eric. The Age of Empire: 1875-1914. London: Weidenfeld and Nic olson, 1987.

Howe, M.A. DeWolfe. "Alan Seeger, Class of 1910." Memoirs of the Harvard 
Dead in the War Aga inst Gemany Vol. 1. Cambridge, MA: Harvard University Press, 1920. 109-24.

Hynes, Samuel. A War Imagined: The First World Warand English Culture. New York: Atheneum, 1991.

Keegan, J ohn. The Face of Battle: A Study of Aginc ourt, Waterloo, and the Somme. New York: Viking, 1976.

Keegan, J ohn. The First World War. New York: Knopf, 1999.

Kennedy, David. Over Here: The First World Warand Americ an Society. 1980 Oxford, Oxford University Press, 2004.

Lears, T.J . Jackson. No Place of Grace: Antimodemism and the Transformation of Americ anCulture, 1880-1920. New York: Pantheon, 1981.

Leed, Eric J. No Man's Land: Combat and Identity in World War 1. Cambridge: Cambridge University Press, 1979.

Losurdo, Domenico. Heideger and the Ideology of War: Community, Death, and the West. Amherst, NY: Huma nity Books, 2001.

Miller, Alisa. "An Americ an Soldier-Poet: Alan Seeger and War Culture in the United States, 1914-1918." First World War Studies 1.1 (2010): 15-33.

Miller, J a mes E. T.S. Eliot: The Making of an Americ an Poet. University Park: Pennsylva nia Sta te University Press, 2005.

Perry, Ralph Barton. "Impressions of a Plattsburg Recruit." The New Republic 4 (1915): 229-31.

Pesc a tello, Ann M. Charles Seeger. A Life in Americ an Music. Pittsburgh: 
University of Pittsb urgh Press, 1992.

Reeves, Harrison. “The Tragedy of Alan Seeger." The New Republic 10 (1917): $160-62$.

Seeger, Alan. Letters and Diary. New York: Charles Scribner's Sons, 1917.

---. Poems. New York: Cha rles Scribner's Sons, 1916.

---. "Suggestions for a Dissertation on the Historic al Development of the Faustmotive: An Essay." bMSAM 1578.1 (7). Houghton Library, Harvard University.

Sibemy, Eliza beth. The New Crusaders: Images of the Crusa des in the 19th and Early 20th Centuries. Ald ershot, UK: Ashga te, 2000.

United Sta tes. Amy. Signal Corps. Pershing 's Crusa ders.UNTDigita I Library. http://digita l.libra ry.unt.edu/ark:/67531/metadc 377/. Accessed 30 J une 2011.

Van Wienen. Mark W. Partisans and Poets: The Politic al Work of Americ an Poetry in the Great War. Cambridge: Cambridge University Press, 1997.

Van Zle, Edward S. "Rise Up! Rise Up, Crusa ders!" Songs of the World War. NY: Philip Goodman, 1918. 77-79.

Willia ms, Raymond. Problems in Materia lism and Culture. London: Verso, 1980; repr. as Culture and Materia lism: Selected Essays. London: Verso, 2005. Word sworth, William. William Word sworth: The Poems, 2 vols. Ed. J ohn O. 
Hayden. New Haven, CT: Yale University Press, 1981. 


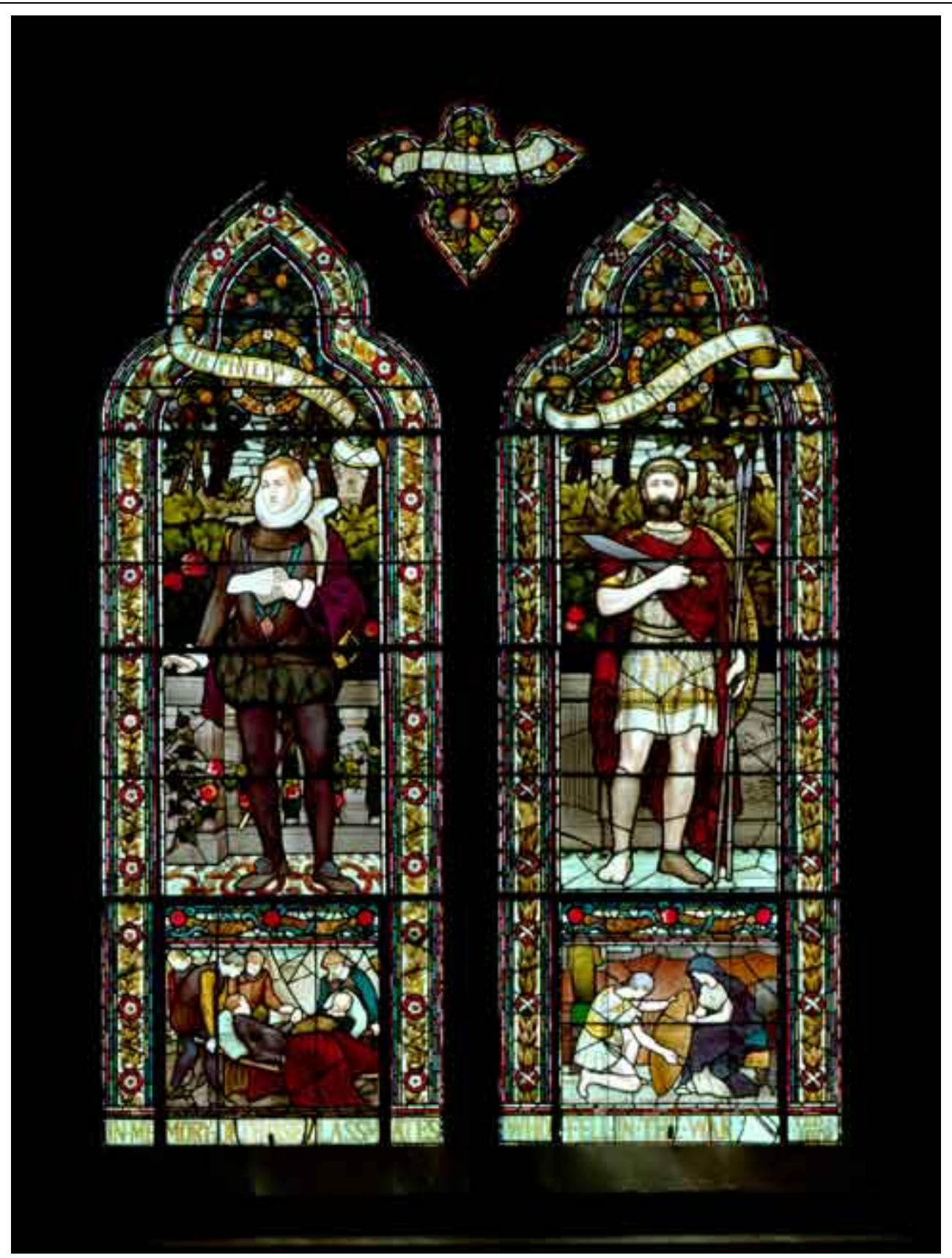

Figure 1. Sta ined glass wind ow by Daniel Cottier depic ting Sir Philip Sidney, Memorial Hall, Harvard University. Depicted on the right is Theban hero Epaminondas. 


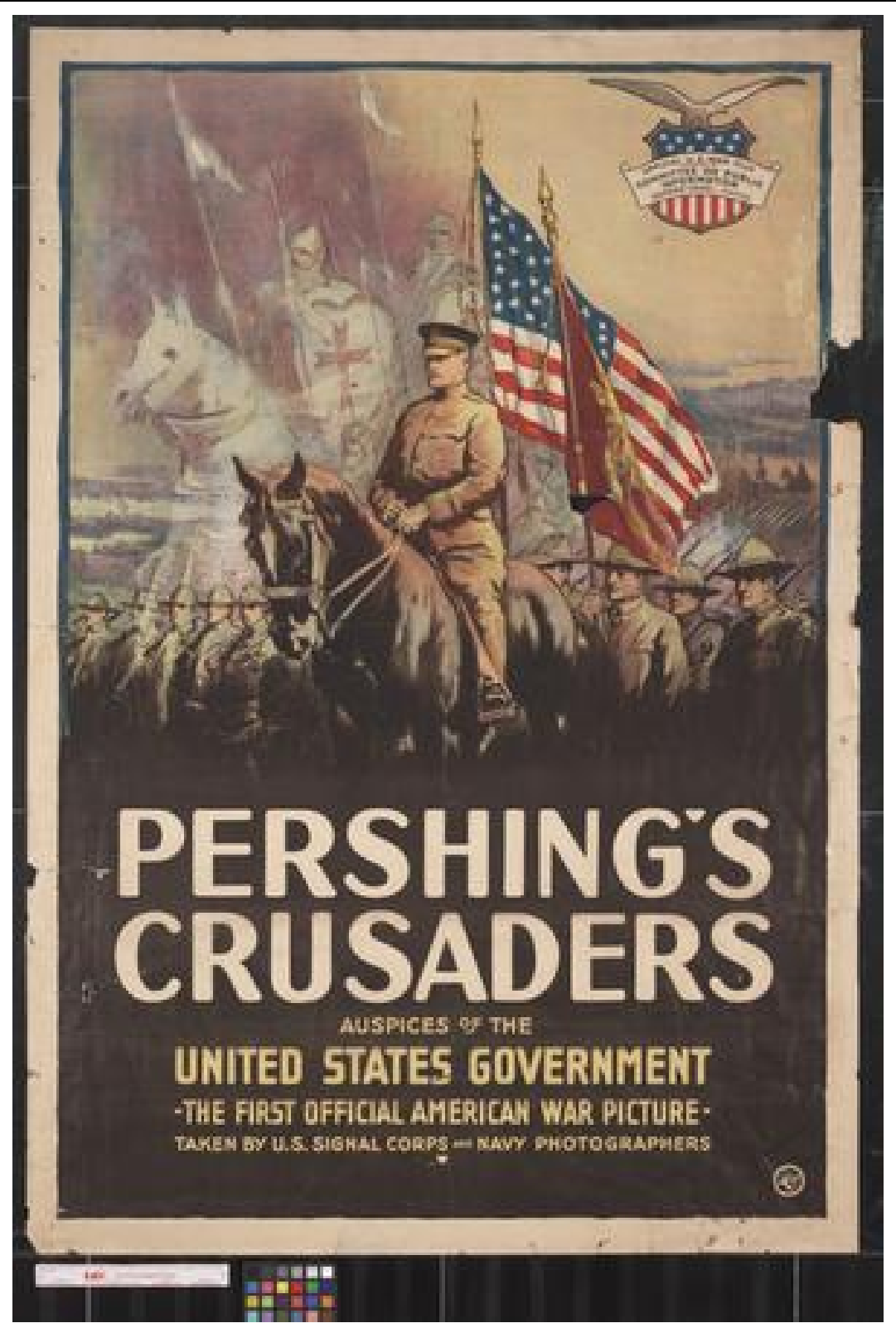

Figure 2. Poster advertising Pershing's C rusaders (1918). 